\title{
A misleading barium enema
}

\author{
Laura Johnson \\ Department of General Surgery, OEQM Hospital, Margate, Kent, UK \\ Correspondence to Laura Johnson, laura.johnson@doctors.org.uk
}

\section{DESCRIPTION}

A 73-year-old obese female patient presented to the outpatient clinic complaining of pain in the right iliac fossa associated with a 2-month history of symptoms suggestive of intermittent subacute bowel obstruction. Her symptoms included pain, abdominal distension and a change in bowel habit with alternating diarrhoea and constipation. She denied any history of rectal bleeding or weight loss and had not undergone any previous bowel investigations or abdominal surgery. Her medical history included ischaemic heart disease, hypertension, renal failure, osteoarthritis and diabetes.

Physical examination demonstrated fullness in the right side of the abdomen with mild tenderness to palpation; examination was however limited by the patients' habitus.

Plain abdominal and chest x-ray were unremarkable and all biochemical parameters were within the normal range with the exception of chronically mildly deranged renal function tests.

An outpatient barium enema was performed as the initial investigation and demonstrated a shouldered 'apple core' lesion in the proximal ascending colon, with narrowing of the lumen but no overt evidence of obstruction (figure 1). This was reported as suspicious for a malignancy.

To further investigate this, a staging CT scan with intravenous contrast enhancement was performed with

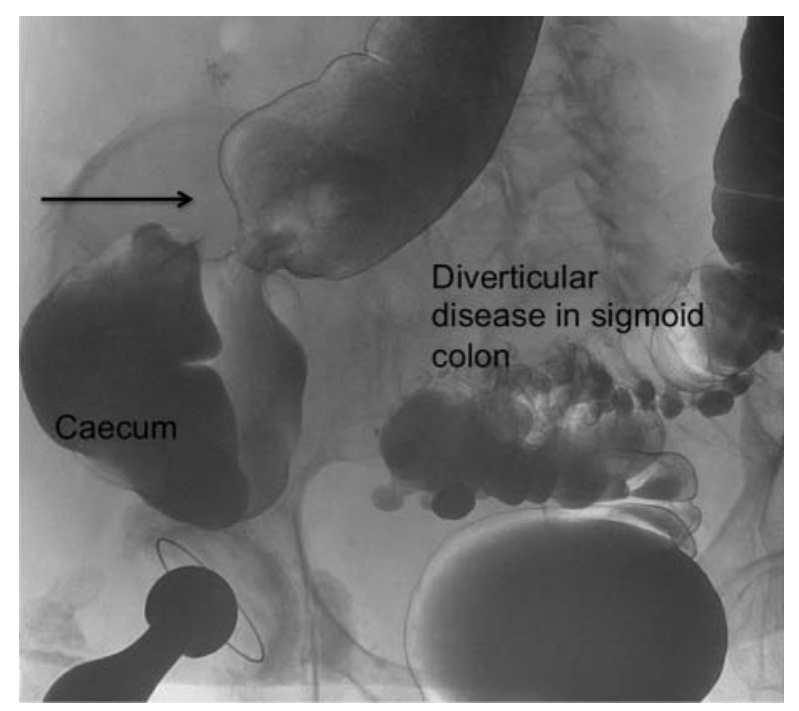

Figure 1 Barium enema clearly demonstrating the shouldered lesion in the proximal ascending colon.

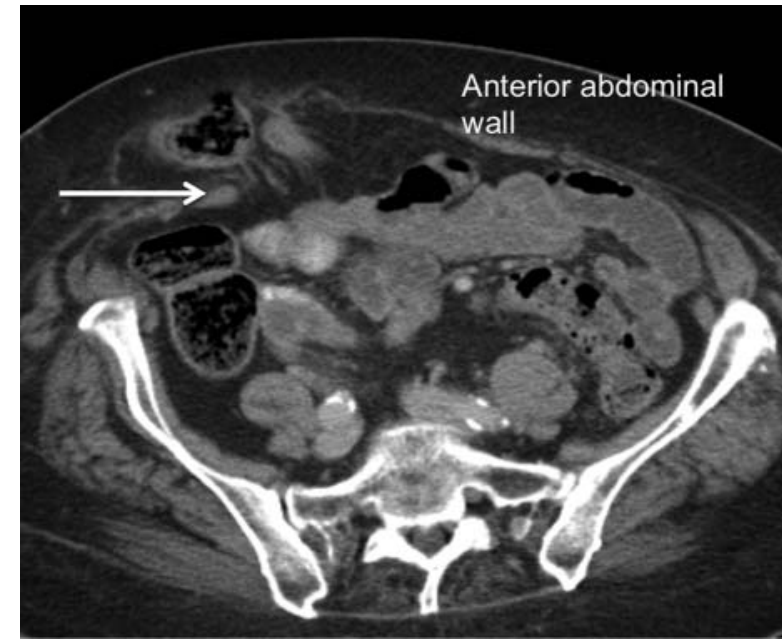

Figure 2 Axial CT scan clearly showing herniation of caecum and ascending colon through the anterior abdominal wall coinciding with the shouldered lesion seen on barium enema.

appropriate intravenous fluid administration to minimise renal injury (figure 2). The CT surprisingly revealed a large anterior abdominal wall hernia containing caecum with no evidence of malignancy. The neck of the hernia contained the proximal ascending colon, resulting in the apparent shouldered lesion seen on barium enema and explaining the symptoms of intermittent obstruction that the patient had initially presented with.

The hernia was surgically managed and the patient made an excellent postoperative recovery with complete cessation of her symptoms.

\section{Learning points}

- Investigations can be misleading especially in the absence of a complete history or examination.

- The diagnosis of malignancy should be made based on multiple modalities to include pathological corroboration to avoid inaccuracies.

Competing interest None.

Patient consent Obtained. 


\section{BMJ Case Reports}

This pdf has been created automatically from the final edited text and images.

Copyright 2012 BMJ Publishing Group. All rights reserved. For permission to reuse any of this content visit http://group.bmj.com/group/rights-licensing/permissions.

BMJ Case Report Fellows may re-use this article for personal use and teaching without any further permission.

Please cite this article as follows (you will need to access the article online to obtain the date of publication).

Johnson L. A misleading barium enema. BMJ Case Reports 2012;10.1136/bcr-2012-006968, Published XXX

Become a Fellow of BMJ Case Reports today and you can:

- Submit as many cases as you like

- Enjoy fast sympathetic peer review and rapid publication of accepted articles

- Access all the published articles

- Re-use any of the published material for personal use and teaching without further permission

For information on Institutional Fellowships contact consortiasales@bmjgroup.com

Visit casereports.bmj.com for more articles like this and to become a Fellow 